\title{
ANALISIS PENGGUNAAN SISTEM BARCODE UNTUK MENDUKUNG PAPERLESS DALAM MENINGKATKAN KEUNTUNGAN FINANSIAL DAN OPERASIONAL
}

\author{
Danny 0ng \\ Sistem Informasi Kampus Kabupaten Karawang \\ Universitas Bina Sarana Informatika \\ www.bsi.ac.id \\ danny.dnx@bsi.ac.id
}

\begin{abstract}
The use of physical paper in the business world today has become a consideration as a waste that can affect the company's financial cycle. The saving of using documents without using physical paper is one way to reduce the company's operating costs, especially for companies that have offices and also some factories in running their businesses. The operational process of non-physical documents is supported by the use of barcodes so that the use of paper is very minimal and management can reduce the company's operational costs to the maximum. This study aims to make observations and analysis of barcode usage related to the effectiveness and efficiency in terms of employee performance and especially financial savings. The results of the study show that in terms of operational expenses of the company that there are benefits of cost savings on physical paper purchases and also employee performance is quite significantly increased in carrying out daily operations because entering data can be done semi-automatically.
\end{abstract}

Keywords: Analysis of Barcode Systems, Non Physical Documents, Company Operations.

Intisari- Penggunaan kertas fisik dalam dunia usaha saat ini banyak menjadi pertimbangan sebagai salah satu pemborosan yang dapat mempengaruhi siklus keuangan perusahaan. Penghematan penggunaan dokumen tanpa menggunakan kertas fisik menjadi salah satu cara untuk mengurangi biaya operasional perusahaan, terlebih lagi untuk perusahaan yang memiliki kantor dan juga beberapa pabrik dalam menjalankan usahanya. Proses operasional dokumen non fisik didukung dengan penggunaan barcode sehingga penggunaan kertas sudah sangat minim dan manajemen dapat mengurangi biaya operasional perusahaan dengan maksimal. Penelitian ini bertujuan melakukan observasi dan analisis terhadap penggunaan barcode terkait efektivitas dan efisiensi dari sisi kinerja karyawan dan khususnya penghematan secara finansial. Hasil penelitian menunjukan dari sisi pengeluaran operasional perusahaan bahwa adanya keuntungan dari penghematan biaya atas pembelian kertas fisik dan juga performa karyawan cukup meningkat secara signifikan dalam menjalankan operasional perusahaan sehari-hari karena memasukan data dapat dilakukan dengan semi otomatis.

Kata Kunci: Analisis Sistem Barcode, Dokumen Non Fisik, Operasional Perusahaan.

\section{PENDAHULUAN}

Teknologi yang semakin berkembang dari waktu ke waktu telah memberikan banyak solusi bagi perusahaan dalam melakukan penghematan terhadap pengeluaran operasional perusahaan. Salah satu pengeluaran yang dapat ditekan terkait dengan operasional perusahaan adalah pengeluaran kertas fisik dalam menjalankan operasional. PT Sangra Ratu Boga merupakan salah satu perusahaan yang banyak mengeluarkan biaya atas penggunaan kertas dalam menjalankan bisnis operasional (Burnham, 2009) karena hampir seluruh aktivitas karyawan masih menggunakan kertas sebagai bahan pokok utama dalam melaksanakan aktivitas hingga pertengahan tahun 2018. Masalah tersebut mengakibatkan perusahaan mengalami kekurangan pendapatan keuntungan (Burnham, 2009) dari operasional bisnis yang sudah dijalankan sehingga diharapkan kedepannya perusahaan dapat meminimalisir pengeluaran tersebut. Tahun 2018 awal, perusahaan sudah direkomendasikan untuk memanfaatkan penggunaan barcode dalam menjalankan bisnis.

Pada penelitian (Gogan \& Rao, 2010) dari sisi penggunaan kertas non fisik (Paperless) hingga data softcopy dapat memberikan layanan yang sudah terenkripsi untuk otentifikasi dokumen secara digital tanpa harus menggunakan cetakan kertas. Dalam (Luse, Mennecke, \& Townsend, 2017) penggunaan Barcode memiliki kekurangan dimana perusahaan harus melakukan investasi tambahan terkait penggunaan barcode 2D yang lebih canggih dibandingkan 1D untuk kebutuhan 
evaluasi karena teknologi 1D sudah ditinggalkan, akan tetapi investasi penggunaan barcode bersifat jangka panjang yang dapat memberikan keuntungan secara menyeluruh.

Tujuan dari penelitian ini adalah melakukan observasi serta melakukan analisis penggunaan barcode untuk mendukung paperless agar dapat bekerja secara maksimal sehingga performa kerja karyawan dapat meningkat serta keuangan perusahaan dapat diminimalisir dari pengeluaran terkait penggunaan kertas yang berlebihan.

$\mathrm{H}_{1}$ : Semakin banyak implementasi penggunaan barcode untuk mendukukung paperless dalam menjalankan operasional perusahan, maka semakin banyak keuntungan secara finansial yang akan diperoleh perusahaan

$\mathrm{H} 2$ : Semakin banyak implementasi penggunaan barcode untuk mendukung paperless dalam menjalankan operasional perusahaan, maka performa karyawan semakin meningkat dalam melakukan operasional bisnis

\section{BAHAN DAN METODE}

Analisis penggunaan paperless membutuhkan penilaian kuesioner (Carr, 2005) mencakup:

1. Responden harus diteliti terlebih dahulu apakah memahami mengenai konsep paperless dan terbiasa bekerja menggunakan data digitial.

2. Responden terhadap adaptasi dari respon yang diberikan oleh karyawan terkait penggunaan format elektronik seperti kertas kerja, data permintaan, penilaian kerja, pesanan pembelian, penjualan dan proses lainnya yang sebelumnya menggunakan kertas.

3. Responden harus diminta penilaian terkait dengan penggunaan paperless apakah dapat mengurangi biaya operasional, waktu dan juga secara tempat yang sebelumnya membutuhkan gudang untuk penyimpanan, kebersihan, produktivitas hingga memudahkan pengiriman data.

Keuntungan paperless dengan menggunakan barcode (Shinya Kato, Chiaki Kobayashi, 2014) adalah pengiritan biaya, efektivitas operasional menggunakan teknologi, data tersimpan jangka panjang dan memiliki history dan data digital dapat disinkronisasi dengan banyak sistem operasional lainnya. Teknologi barcode memberikan optimasi terhadap keseluruhan operasional dalam melakukan pengawasan nilai persediaan dan penguatan pusat distribusi produk kepada konsumen (Prokopovic, Prokopovic, \& Jelic, 2016). Keuntungan penggunaan barcode lainnya yaitu menyediakan keakuratan data dan juga menjadi solusi operasional, memberikan potensi untuk menjaga biaya dan waktu yang akan mengurangi potensi kesalahan dan membantu proses internal maupun eksternal dalam operasional dan menyediakan proses yang baik antara pendistribusian barang dan arus data informasi elektronik.

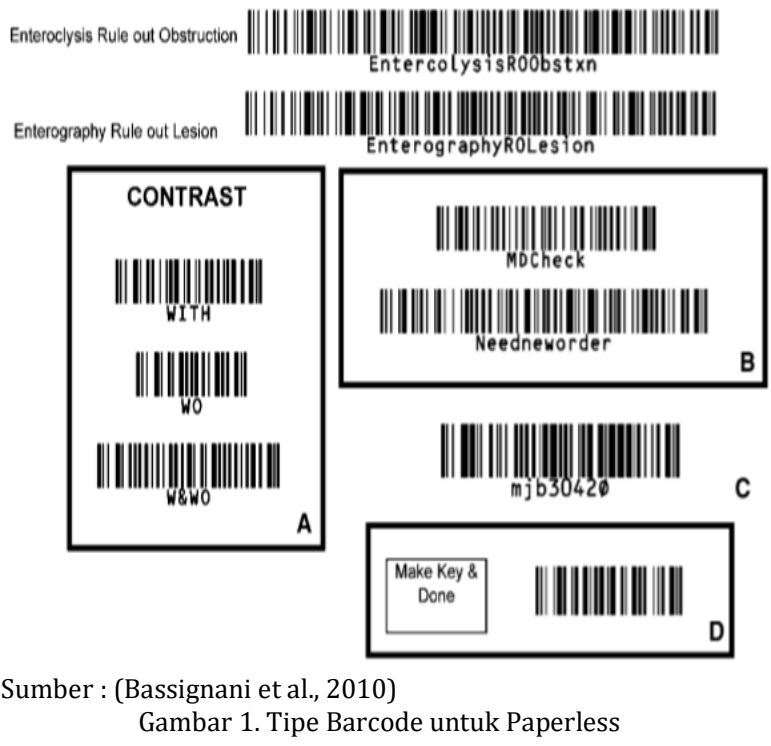

Kertas Barcode dalam penggunaannya harus memperhatikan kejelasan serta fungsi yang akan digunakan untuk memudahkan pembagian fungsi (Bassignani, Dierolf, Roberts, \& Lee, 2010). Contoh penggunaan barcode yang sesuai dengan fungsi masing-masing pada Gambar 1. Metode dalam penggunaan barcode adalah melakukan standarisasi terlebih dahulu terhadap objek-objek yang ditunjuk untuk pemasangan barcode dan selanjutnya akan dihubungkan dengan sistem untuk melakukan operasional dengan scanner oleh tim dalam meningkatkan kecepatan performa kerja karyawan.

Proses penelitian (Gambar 2) terkait dengan analisis penggunaan sistem barcode untuk mendukung paperless dengan metode Balance Scorecard (Rotchanakitumnuai, 2013) yang juga akan dilakukan evaluasi dengan metode perbandingan yang akan dijelaskan sebagai berikut :

1. Survei Literature dan Studi Pustaka

Peneliti akan mengumpulkan informasi dari jurnal penelitian sebelumnya yang terkait. Kemudian dari survey literature tersebut, peneliti akan melengkapi dan mendetailkan lebih jauh terkait dengan pemanfaatan sistem yang akan menjadi bagian dari proses pendetailan dari keuntungan bagi perusahaan

2. Identifikasi Masalah

Melakukan identifikasi terkait permasalahan yang akan dilakukan penelitian mengenai analia penggunaan barcode untuk mendukung paperless pada studi kasus PT Sangra Ratu Boga 
3. Melakukan Hipotesis

Hipotesis awal yang dirumuskan oleh peneliti adalah: Apakah ada pengaruh penggunaan barcode dalam mendukung paperless dapat meningkatkan performa karyawan dalam menjalankan operasional bisnis perusahaan? Dan apakah ada pengaruh penggunaan barcode dalam mendukung paperless dapat memberikan keuntungan secara finansial bagi perusahaan.

4. Observasi, Wawancara dan Kuesioner

Penelitian akan dilakukan dengan melihat secara langsung proses dan data yang terjadi didalam perusahaan, melakukan wawancara dengan pihak yang berkepentingan serta menggunakan kuesioner untuk mempertajam analisis penelitian yang akan dilakukan

5. Melakukan Analisis

Peneliti akan menganalisis dan mengolah data yang diperoleh dan memberikan nilai dari masing-masing data yang diperoleh. Setelah dilakukan analisis secara detail maka selanjutnya akan diambil esensi yang utama terkait dengan pemanfaatan yang menjadi sasaran dalam meningkatkan performa finansial dan juga peningkatan operasional dari setiap karyawan pabrik

6. Menarik Kesimpulan dan Memberi Saran Setelah dilakukan analisis lebih lanjut maka peneliti akan memberikan kesimpulan terkait pengujian hipotesis yang dirumuskan serta memberikan saran yang baik untuk bisnis perusahaan kedepannya menjadi lebih baik.

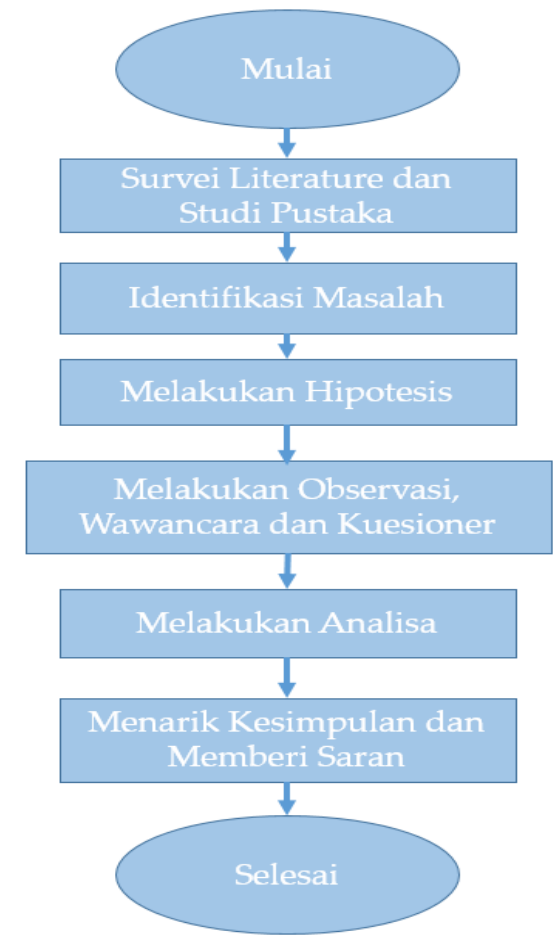

Gambar 2. Tahap Penelitian

\section{HASIL DAN PEMBAHASAN}

Dari hasil evaluasi dan penelitian yang dilakukan oleh peneliti ditemukan bahwa dengan dilaksanakannya penelitian menunjukan bahwa operasional karyawan serta peningkatan finansial perusahaan dalam penggunaan sistem barcode untuk mendukung paperless memberikan hasil yang positif.

Hasil yang diperoleh dari penelitian yang menggunakan konsep balance scorecard adalah dari segi keuangan, tedapat ancaman finansial menurun apabila investasi yang dilakukan tidak cocok dengan divisi bersangkutan. Peluangnya adalah keuntungan berlebih apabila diterapkan terhadap seluruh divisi dalam pelaksanaan paperless. Kekuatannya adalah penambahan keuntungan dari sisi finansial karena terjadi pengurangan terhadap pengeluaran kertas fisik dan kelemahannya diperlukan investasi diawal untuk penggunaan barcode dan paperles.

Dari segi pelanggan, terdapat ancaman berupa beberapa pelanggan yang tetap membutuhkan penggunaan kertas fisik dalam transaksi. Peluangnya adalah keselarasan konsep dengan pelanggan sehingga transaksi juga dapat dilakukan secara paperless. Kekuatannya adalah pemahaman keuntungan bersama-sama secara finansial dan operasional apabila menerapkan konsep yang sama dan kelemahannya perlu dilakukan pemberian pemahaman untuk menerapkan hal yang sama.

Dalam proses internal, ancamannya adalah permasalahan operasional lebih rendah apabila proses pengerjaan tidak dipahami secara menyeluruh. Peluangnya adalah seluruh divisi memiliki performa operasional meningkat dari sisi kecepatan dan hasil pengerjaan yang lebih maksimal. Kekuatannya adalah operasional menjadi lebih cepat dari sebelum menggunakan paperless dan meminimalisir penggunaan kertas fisik dan kelemahannya adalah keselarasan antar karyawan dalam menjalankan konsep dan operasional pada divisi yang sama harus berjalan baik.

Dalam pembelajaran dan pertumbuhan, ancamannya adalah karyawan dengan tingkat pemahaman dan kecepatan adaptasi yang berbeda-beda dapat memberikan pengaruh positif dan negatif dalam menjalankan operasional. Peluangnya adalah Peningkatan daya tangkap dan daya saing pada masing-masing karyawan untuk dapat berkembang lebih baik. Kekuatannya adalah Peningkatan performa dan adaptasi penggunaan sistem untuk mendukung operasional .Kelemahan nya adalah Karyawan dengan tingkat usia lanjut yang berpeluang untuk menghambat masa adaptasi dan penggunaan sistem. 
Tabel 1. Perbandingan Penilaian Penggunaan Kertas

\begin{tabular}{ccc}
\hline Kriteria & Jumlah & Nilai \\
\hline Penggunaan & 3501 Rim & 1 \\
Kertas & 201-500 Rim & 2 \\
Operasional & 101-200 Rim & 3 \\
& $<100 \mathrm{Rim}$ & 4 \\
& & 5 \\
\hline
\end{tabular}

Tabel 2. Perbandingan Penilaian Performa Operasional

\begin{tabular}{ccc}
\hline Kriteria & Waktu & Nilai \\
\hline Peningkatan & 20\% Lebih cepat & 1 \\
Performa & 40\% Lebih Cepat & 2 \\
Operasional & 60\% Lebih cepat & 3 \\
(Waktu & 80\% Lebih Cepat & 4 \\
Penyelesaian & 100\% Lebih Cepat & 5 \\
Pekerjaan) &
\end{tabular}

Tabel 3. Realisasi Penggunaan Kertas dan Performa Operasional

\begin{tabular}{lcc}
\hline & $\begin{array}{c}\text { Penggunaan Kertas } \\
\text { Operasional }\end{array}$ & $\begin{array}{c}\text { Perfoma } \\
\text { Operasional }\end{array}$ \\
\hline Jul'17 & 623 & - \\
Aug'17 & 594 & - \\
Sep'17 & 637 & - \\
Okt'17 & 520 & - \\
Nov'17 & 602 & - \\
Des'17 & 507 & - \\
Jan'18 & 489 & - \\
Feb'18 & 476 & - \\
Mar'18 & 543 & - \\
Apr'18 & 582 & - \\
Mei'18 & 530 & - \\
Jun'18 & 223 & $60 \%$ \\
Jul'18 & 242 & $60 \%$ \\
Aug'18 & 189 & $80 \%$ \\
Sep'18 & 192 & $80 \%$ \\
Okt'18 & 202 & $60 \%$ \\
Nov'18 & 132 & $80 \%$ \\
Des'18 & 147 & $80 \%$ \\
\hline
\end{tabular}

Berdasarkan hasil penelitian ditemukan beberapa pertemuan dari hasil survey lapangan dan juga wawancara yang dilakukan terhadap beberapa narasumber yaitu pada Tabel1. Bobot penilaian dari penggunaan kertas fisik dalam jumlah rim oleh divisi operasional pada perusahaan tergolong besar, oleh sebab itu dilakukan bobot penilaian terhadap penggunaan kertas dengan melakukan pemberian nilai 1-5 dilihat dari jumlah besar kertas yang dikeluarkan. Bobot penilaian dari perfoma terkait dengan waktu penyelesaian suatu tugas oleh karyawan juga diukur dari penggunaan sistem barcode, dimana bobot penilaian juga diperhitungkan dari skala 1-5 (Tabel 2). Dari hasil penelitian dan pengumpulan data yang dilakukan oleh peneliti dari sebelum dan sesudah penggunaan barcode untuk mendukung konsep paperless, maka didapat hasil dari kegiatan operasional yang terjadi di perusahaan sesuai dengan data pada Tabel 3 .

Hasil penelitian Tabel 4 merupakan pemberian bobot atas hasil evaluasi, wawancara dan pengumpulan data yang dilakukan oleh peneliti sehingga diperoleh nilai yang menentukan bahwa hipotesa yang diperoleh menunjukan bahwa adanya perbaikan yang sangat signifikan dari hasil penggunaan barcode atas konsep paperless untuk mendukung kemanjuan finansial dan operasional.

Proses penelitian (Gambar 3), observasi dan wawancara dilakukan sesuai dengan prosedur yang sudah dirumuskan untuk memastikan bahwa hipotesa-hipotesa dalam penggunaan barcode memberikan pengaruh perbaikan dan peningkatan secara finansial dan perfoma.

Table 4. Realisasi Penilaian Penggunaan Kertas dan Performa

\begin{tabular}{lcc} 
& $\begin{array}{c}\text { Operasional } \\
\text { Bobot Nilai } \\
\text { Paperless }\end{array}$ & $\begin{array}{c}\text { Bobot Nilai } \\
\text { Operasional }\end{array}$ \\
\hline Jul'17 & 1 & - \\
Aug'17 & 1 & - \\
Sep'17 & 1 & - \\
Okt'17 & 1 & - \\
Nov'17 & 1 & - \\
Des'17 & 1 & - \\
Jan'18 & 2 & - \\
Feb'18 & 2 & - \\
Mar'18 & 1 & - \\
Apr'18 & 1 & - \\
Mei'18 & 1 & - \\
Jun'18 & 1 & 3 \\
Jul'18 & 3 & 3 \\
Aug'18 & 3 & 4 \\
Sep'18 & 4 & 4 \\
Okt'18 & 4 & 3 \\
Nov'18 & 4 & 4 \\
Des'18 & 3 & 4 \\
\hline
\end{tabular}

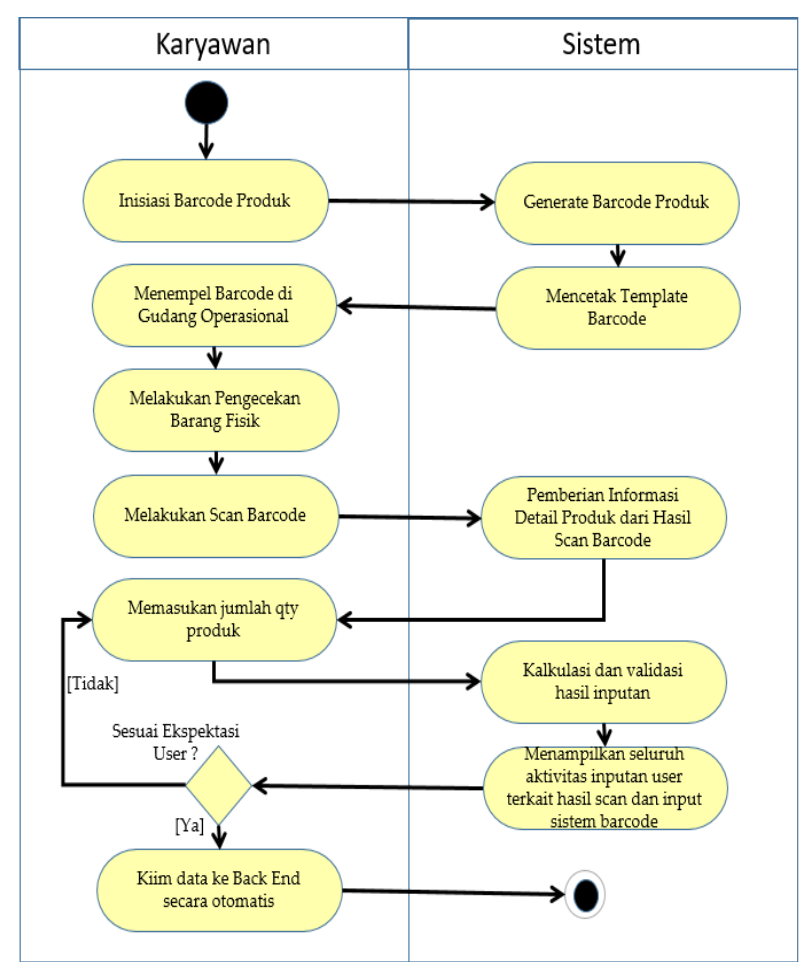

Gambar 3. Proses Alur Penelitian 
Tabel 5. Pengukuran Keberhasilan

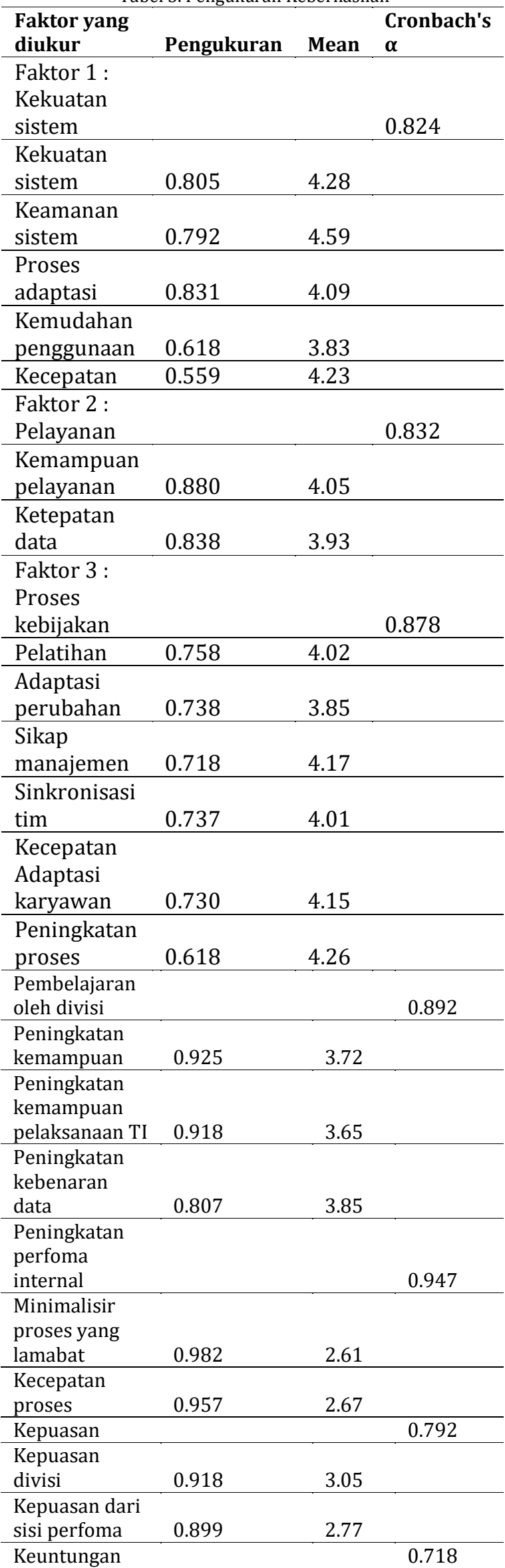

\begin{tabular}{|c|c|c|c|}
\hline $\begin{array}{l}\text { Faktor yang } \\
\text { diukur }\end{array}$ & Pengukuran & Mean & $\begin{array}{l}\text { Cronbach's } \\
\alpha\end{array}$ \\
\hline $\begin{array}{l}\text { Faktor 1: } \\
\text { Kekuatan } \\
\text { sistem }\end{array}$ & & & 0.824 \\
\hline $\begin{array}{l}\text { Kekuatan } \\
\text { sistem }\end{array}$ & 0.805 & 4.28 & \\
\hline $\begin{array}{l}\text { Keamanan } \\
\text { sistem }\end{array}$ & 0.792 & 4.59 & \\
\hline $\begin{array}{l}\text { Proses } \\
\text { adaptasi }\end{array}$ & 0.831 & 4.09 & \\
\hline $\begin{array}{l}\text { Kemudahan } \\
\text { penggunaan }\end{array}$ & 0.618 & 3.83 & \\
\hline Kecepatan & 0.559 & 4.23 & \\
\hline $\begin{array}{l}\text { Faktor 2: } \\
\text { Pelayanan }\end{array}$ & & & 0.832 \\
\hline $\begin{array}{l}\text { Kemampuan } \\
\text { pelayanan }\end{array}$ & 0.880 & 4.05 & \\
\hline $\begin{array}{l}\text { Ketepatan } \\
\text { data }\end{array}$ & 0.838 & 3.93 & \\
\hline $\begin{array}{l}\text { Faktor } 3 \text { : } \\
\text { Proses } \\
\text { kebijakan }\end{array}$ & & & 0.878 \\
\hline Pelatihan & 0.758 & 4.02 & \\
\hline $\begin{array}{l}\text { Adaptasi } \\
\text { perubahan }\end{array}$ & 0.738 & 3.85 & \\
\hline $\begin{array}{l}\text { Sikap } \\
\text { manajemen }\end{array}$ & 0.718 & 4.17 & \\
\hline $\begin{array}{l}\text { Sinkronisasi } \\
\text { tim }\end{array}$ & 0.737 & 4.01 & \\
\hline $\begin{array}{l}\text { Kecepatan } \\
\text { Adaptasi } \\
\text { karyawan }\end{array}$ & 0.730 & 4.15 & \\
\hline $\begin{array}{l}\text { Peningkatan } \\
\text { proses }\end{array}$ & 0.618 & 4.26 & \\
\hline finansial & & & \\
\hline $\begin{array}{l}\text { Pengurangan } \\
\text { biaya }\end{array}$ & 0.857 & 3.42 & \\
\hline $\begin{array}{l}\text { Alokasi biaya } \\
\text { ke arah } \\
\text { peningkatan } \\
\text { perfoma }\end{array}$ & 0.879 & 3.02 & \\
\hline
\end{tabular}

Dari hasil analisis dan penelitian yang dilakukan terkait dengan tolak ukur pengukuran keberhasilan pelaksanaan barcode dalam mendukung paperless menunjukan bahwa terjadi peningkatan secara finansial dalam melakukan minimalisir terhadap pengeluaran serta meningkatkan perfoma karyawan dalam melaksanakan proses operasional (Tabel 5).

Hasil penilaian secara menyeluruh dari proses penelitian yang dilakukan menguatkan hipotesa awal yaitu bahwa semakin dilakukan perluasan dalam penggunaan barcode untuk paperless maka keuntungan perusahaan dari sisi finansial ataupun operasional akan semakin baik, dapat dilihat pada Tabel 6. 


\section{KESIMPULAN}

Berdasarkan hasil penelitian yang dilakukan terkait analisis penggunaan sistem barcode untuk pelaksanaan paperless, performa karyawan dalam menjalankan proses operasional khususnya pada divisi gudang menjadi lebih meningkat karena proses penginputan stock opname lebih cepat. Penggunaan barcode yang sudah terhubung dengan sistem meningkatkan kualitas ketepatan data karena tercatat history dan dapat dievaluasi. Efisiensi pengeluaran finansial secara operasional khususnya penggunaan kertas fisik dapat dikurangi. Hasil penelitian juga menunjukan bahwa ada potensi keuntungan berlipat juga dapat diperoleh dari menggunakan konsep paperless pada proses operasional eksternal jika dilakukan analisis lebih lanjut.

\section{REFERENSI}

Bassignani, M. J., Dierolf, D. A., Roberts, D. L., \& Lee, S. (2010). Paperless protocoling of CT and MRI requests at an outpatient imaging center. Journal of Digital Imaging, 23(2), 203210.

Burnham. (2009). Clients Helped to Reduce Costs Associated with Paper Consumption. International Journal of Micrographics \& Optical Technology, 27(3), 17-18.

Carr, M. R. (2005). An analysis of the feasibility of a paperless environment - the case of the Mona School of Business. Management of Environmental Quality: An International Journal, 16(4), 286-290.

Gogan, J. L., \& Rao, A. (2010). Barcodes, RFIDS, lemonade and conversation. Journal of Information Technology, 25(4), 450-456.

Luse, A., Mennecke, B., \& Townsend, A. (2017). Electronic Forms-Based Computing for Evidentiary Analysis. Journal of Digital Forensics, Security and Law, 4(3), 17-35.

Ong, D. (2019). Analisis Penggunaan Sistem Barcode untuk Mendukung Paperless dalam
Meningkatkan Keuntungan Finansial dan Operasional Pada PT Sangra Ratu Boga.

Prokopovic, K., Prokopovic, T., \& Jelic, M. (2016). Information technologies in integrated logistics. Ekonomika, 62(1), 175-186.

Rotchanakitumnuai, S. (2013). Assessment of eprocurement auction with a balanced scorecard. International Journal of Physical Distribution and Logistics Management, 43(1), 39-53.

Kato Shinya, Kobayashi Chiaki Nakanishi Yuko. (2014). Children Examination of the clinical significance of procalcitonin in fever diseaseFocusing on Kawasaki disease-, 4 (4), 561 565. 